\title{
感應理論の㸴究(第二十一報告)
}

— 感㗹の時間測定的研究—

日本大學心理學研究室

小保丙虎夫

I 問 題

筆者は今迄，感鹤現象に關して種ふな方面から筫驗を試みたが，併しそ礼等の多くは

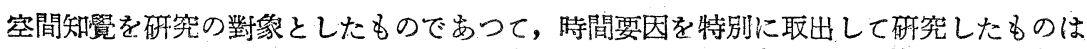
餘り多くはない。墽に報告した音韻同化, 繼次的同化・對比, 感應再生, 視野交替, \ イグール・グルント交替等の諸研究は何れる時間を問題としたものであるが，牦しそれ でもまだ一二のタのを除げば時間要因が䂧究の主題となる所まで行つてるない。そこで 本諭文では特にこの時間要因を取上げ，これを筫驗的咑究の對象とすることにした。而

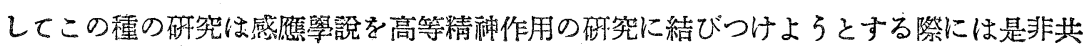
必要な事柄である。何んとなれば高等精神作用は時間過程に颃いてその本姿を顯はすこ とが多いからこれを研究しよらとすれば勢ひ特間要因を手掛りとせざるを德ないから である。更にまた生理學と心理學との聯絡る圖ることは心理學にとつて重要な課題であ るがここれをなす上にこの種の研究が不可避のるのである。、生理學における所謂禁止・ 促進なるものが感應の時間的側面之密姧な關係のあることに思ひ到るならばこのことは 容易に首肯されるであらう。かやうなわけで, 感應の時間的䂰究といるものが心理學に とつて電要な意義を有する所以が理解される。

では一體如何なる方法によつてこの問題を破究せんとするのであるか。筆者の研究考 想を簡單に言ふならば, 宾間感應における過大視域・過小哯域に應じて對呂認知時間に 如何なる變化が起るかを調べるにある。一方,これを補ふ目的をもつてこの兩域におい て辨別感受性・(剌践闘) がどう變るかを調べる。かくして空間感應が時間的側面におい

1）小保內虎夫・板倉善高：昔韻同化の研究「教育心理研究」9(1934) 257-287

2）小保内虎夫・佐藤芳藏：繼次的同化・對比の研究「心理舉研究」12 (1937) 451一 464.

3）小保內虎夫：感應再生火關する實驗「心理學研究」13 (1938) 364-377.

4) 小保內虎夫・篠原久男：新しい見地から行つた視野交替惯驗「沁理學研究」 $17(1$ 942) $151-168$.

5）小保內虎夫：フイグール・グルント現象の感㶝心理學的皏究「心理學研究」14 (1 $943)$ 特號, 11 . 
て如何なる性質を有するかを明かにするのである。以下か〉る考想に基づいて行つた實 驗の結梁孝報告する。

\section{II 感應と認知時間}

[目的]圖1（イ）において中央の線の長さを變へると，それに應じて外側二點間距

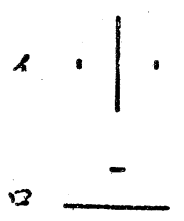

國 1

離も筱化して見え，過大視過小視の兩域が成立することについては 既に述べた所である。この場合，空聞以外の他の屬性師ち時間に關 してどうなるかといふことを調べるのが本節の實驗の目的である。 [方法】これがために次のやうな筫驗を試みた。いま圖 $1($ 口)圖 形一一（イ）圖形の纞形一ーを刺战圖形となし, 長線 (影響線)の上 部に描かれてるる短線 (被影響線) が認知されるに要する時間を測定する。すると下方 にある線の大小に應じて認知時間に變動が起る。それを測定によつて明かにしようとす るのである。

實驗の遺方は次の通りである。鿓驗開始に先だち各被驗者について函め觀察距離を決 定する。これは短線だけを描いた圖形を呈示し，それが辛うじて認知出來る距離によつ てきめられる。この距離は被驗者の視覺感受性の良否により區々であることは言ら汽も ない。各被驗者の觀察距離は表Ｉに揭げてある故, 參されたい。觀察包數は各圖形に ついて 3 包乃至 5 包。

【被驗者】心理學者及び心理學專攻學生合計 8 名。

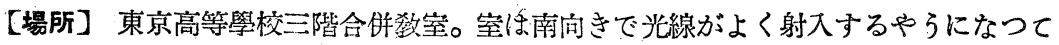
るる。

[時期] 䁈驗は一部分は數年前に行つたものであるが，本報告の主姴部分は昭和17年 春以降に行つたものである。

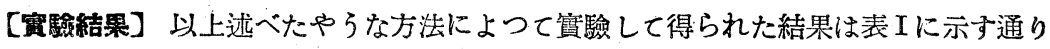
である。8名の被驗者に對する本均をグラフに示すと圖 2 のやうになる。グラフによつ て明かであるやらに, 影響線が長くなるにつれて認知特間が短縮し, ある場所を境とし て反對に延長の方向に轉ずる。このやうに認知時間が短縮したり延長したりすることは 知覺過程が夫々促進及び禁止を受けてるるためと解することが出來る。所で, この禁止 效果は線よりを矩形を用ひた場合の方が一層著しい故, 次に矩形を影響剌战とした圖形

1）小保內虎夫：感磼の基本法則「心理學研究」11 (1936) 450-461. 
について筫驗を試みた。

いま圖 3 の圖形において矩形の大きさを變へた場合，短線に對する認知特間に如何 表 I

\begin{tabular}{|c|c|c|c|c|c|c|c|}
\hline 被 & 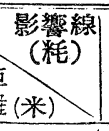 & 2.5 & 5.0 & 10.0 & 40.0 & 80.0 & 單獨線 \\
\hline 小○○ & 1.30 & 19.7 & 4.3 & 3.2 & 6.0 & 13.0 & 17.7 \\
\hline 中 $O$ & 12.2 & 59.0 & 8.3 & 4.1 & 12.5 & - & 8.3 \\
\hline 村 $\bigcirc$ & 12.0 & 14.7 & 6.2 & 7.9 & 5.4 & - & 8.5 \\
\hline 野 0 & 13.4 & 17.0 & 6.5 & 2.7 & 16.5 & 8.5 & 7.5 \\
\hline 妻 0 & 12.5 & 11.5 & 4.0 & 5.5 & 6.8 & 11.5 & 13.8 \\
\hline 正 $O$ & 11.7 & 20.0 & 5.3 & 3.1 & 6.0 & 13.0 & 16.0 \\
\hline 平 0 & 10.4 & 19.3 & 14.8 & 7.0 & 43.0 & 37.0 & 33.5 \\
\hline 古 $\bigcirc$ & 11.1 & 11.0 & 6.5 & 5.7 & -1 & 42.0 & 18.0 \\
\hline 平 均 & & 21.5 & 7.0 & 4.9 & 13.7 & 10.8 & 15.4 \\
\hline
\end{tabular}

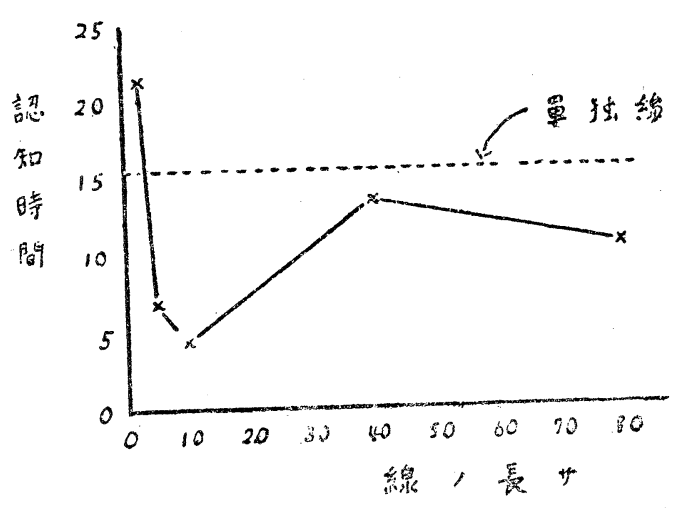

㽞 2

表 II

なる變化が起るか 調べる。矩形の横 偪を一定にし，(5 粍), 縱の長さだけ 方蘩へる。短線の 图 3 長さ 5 粍,太さ 0.2 粴。短線と矩形との距離 10 粍。測定結果は表 II に示す 通りである。3名に對する本 均をグラフに示したのが圖 4 である。

\begin{tabular}{|c|c|c|c|c|c|c|c|c|c|}
\hline 被 譥 & 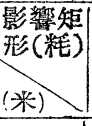 & 0.2 & 0.4 & 0.6 & 0.8 & 1.6 & 3.2 & $6 . \dot{4}$ & 單獨線 \\
\hline 小०O & 13.0 & 12.3 & 4.7 & 3.0 & 1.7 & 13.0 & 6.0 & 8.7 & 5.0 \\
\hline 毒 & 12.3 & 27.0 & 9.5 & - & 2.3 & 17.2 & 28.3 & $\infty$ & 10.0 \\
\hline 野 0 & 12.9 & 19.2 & 5.7 & - & 8.8 & 11.7 & 14.8 & $\infty$ & 15.8 \\
\hline 本均 & & 19.4 & 5.5 & 3.0 & 4.3 & 14.0 & 15.4 & $\infty$ & 10.3 \\
\hline
\end{tabular}




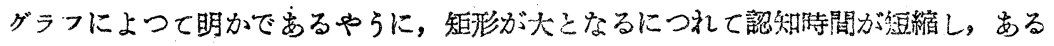

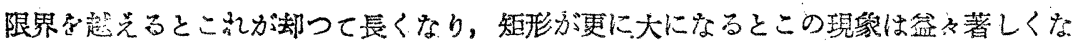

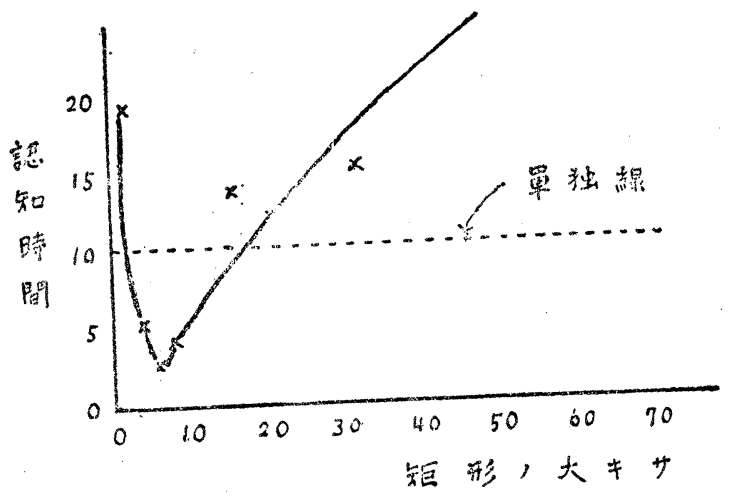

四 4 る。前述のや弓に線老影響刺 㦸として用ひた場合にもこの 關係が認められたが，矩形を

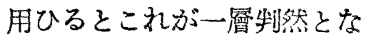
る。

所で, 影響效果に關して線

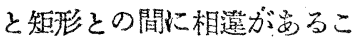
とは他の筫驗結果によつても 琴書される。それは次のやう

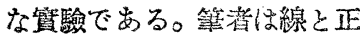
方形とが各々面稳の等しい場

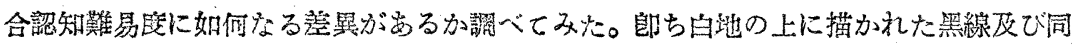

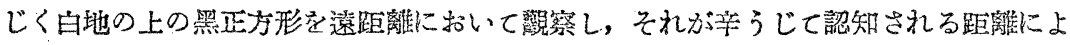

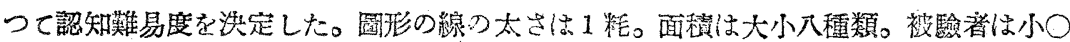

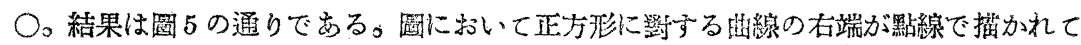

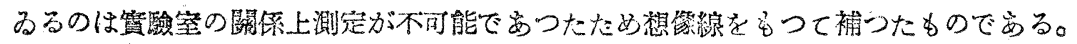
ま大視力以觀察距離（米）によつて示されてるる。グラフによつて明かであるやうに， 線と正方法とでは面積才゙等しく

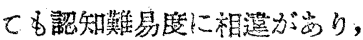
正方形の分が，より一虔容易で

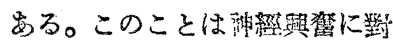
して正方形の方が一層效洜的で あることを意味する。

このやうな次第で，正方形は

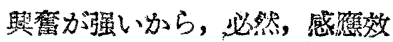
果も强く、これが上に述べた矩 形の感應效果の特资を生んだも のであらら。

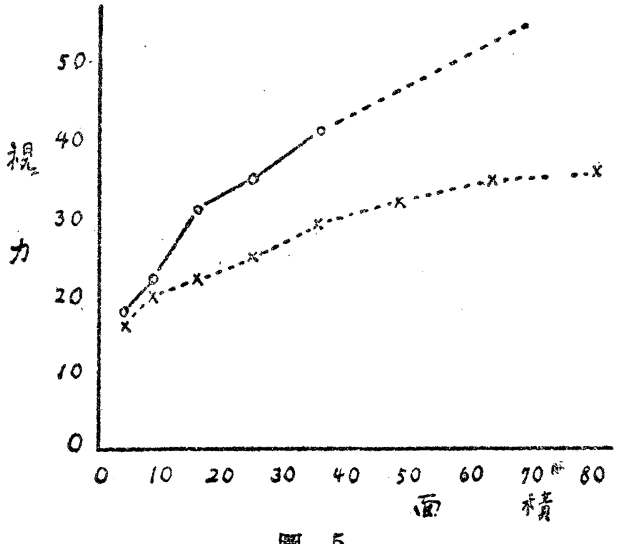

活 5

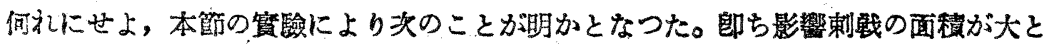


なる特は被影響刺戱の認知が初めは促進的影響を受けこれが页に大になると禁止的影 整を受けるやうになる。

\section{III 感應己認知時間(續き)}

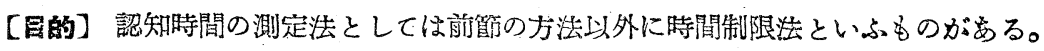
本節ではこの方法による研究の結喿を述べる。

【方法】前節の䆩驗において用ひた圆形を使用し，これを 0.5 秒及び 1 秒間呈示して

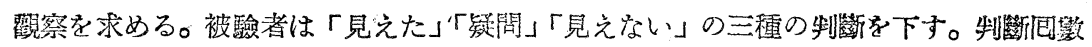
を統計して認知度を表はす。觀察距離は 13.3 米。被驗者は小○○。

【䋨舆]結果は紊 IIIに示す通りである。これによれば，影響線の長さと認知時間を の間には前節の實驗におけると類似した關係の存することが制る。但し本篔の筫驗にお

表 III

\begin{tabular}{|c|c|c|c|c|c|c|c|}
\hline $\begin{array}{l}\text { 哇時 } \\
\text { 間愁 }\end{array}$ & 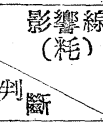 & 2.5 & 5.0 & 10.0 & 20.0 & 40.0 & 單獨線 \\
\hline 0.5 & $\begin{array}{l}\text { 見エタ } \\
\text { 筩 問 } \\
\text { 見エズ }\end{array}$ & $\begin{array}{l}2 \\
2\end{array}$ & $\begin{array}{l}3 \\
1\end{array}$ & $\begin{array}{l}2 \\
2\end{array}$ & $\begin{array}{l}2 \\
2\end{array}$ & $\begin{array}{l}2 \\
2\end{array}$ & $\begin{array}{l}2 \\
2\end{array}$ \\
\hline 1.0 & $\begin{array}{l}\text { 見エ夕 } \\
\text { 疑 問 } \\
\text { 見エズ }\end{array}$ & 4 & 4 & 4 & $\begin{array}{l}1 \\
2 \\
1\end{array}$ & 4 & 4 \\
\hline 合 訫 & $\begin{array}{l}\text { 見エタ } \\
\text { 㹣 問 } \\
\text { 見エズ }\end{array}$ & $\begin{array}{l}2 \\
6\end{array}$ & $\begin{array}{l}7 \\
1\end{array}$ & $\begin{array}{l}6 \\
2\end{array}$ & $\begin{array}{l}3 \\
4 \\
1\end{array}$ & $\begin{array}{l}6 \\
2\end{array}$ & $\begin{array}{l}2 \\
6\end{array}$ \\
\hline & 差 & +2 & +7 & +6 & +2 & -2 & -6 \\
\hline
\end{tabular}

いては單猲總に斨する認知時間は著しく不良である。これは感應效果白身の性質による

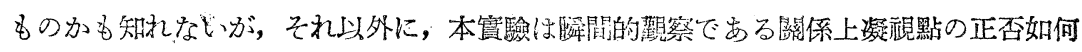

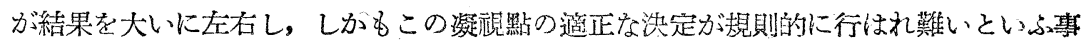
情によることも磪かである。これを考慮に容れるならば單蔃線に對する認知度はもつと 佳良と見てよいであらう。

いま制斷の條件について述べる所があつたから，序に前節の獀驗に關聯して氣づいた

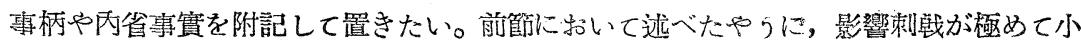


さい場合には短線に對する認知時間は單獨線に對するそれよりれ琹い。但しこれは 8 名 の本均值について言はれることであつて個別的に見れば必ずしもさろではない。郎ち 4 名においては前者に對する認知時間が惡いし，他の 4 名はこれに反し佳良である。而し てからる差異の原因は視神經機構の個人差にあるよりは篹ろ判斷標準のとり方如何にあ るやらに思はれる。何んとなれば前者郎ち影響刺㦸線の小なる圖形にあつては短線（被 影響線)と影響線とが一緒になつて淡い斑點となつて見える。この時「見えた」と答へ れば認知時間は短くなるし，これに反し短線が影響線からハッキリと離れてから反應す れば認知時間は遲くなる。この邊の呼吸が人によつて違つてるる。これに加ふるに各人 の觀察距離の相違に基づく圖形印象の差異も考慮に容れなくてはならない。このやらに 考へて來ると時間測定は仲々デリヶートな問題を含んでるることが制る。一體，いまの 場合に限らず時間測定なるるのは抑々甚だ難かしいものである。反應時間はいま述べた やらに被驗者の意志や態度により左右されるばかりでなく, 觀察の際の外部條件によつ ても影響されて仲々規則的な值を示して呂れない。また觀察距離の浃定も言葉で言ら樣 には簡單にいかない。しかもそれ等の適否如何が結果に大きな影響を及ぼすのである。 かやうなわけで，今四の珼驗は誰でもが自動的に操作して簡單に結果を出し得るもので はない。實驗者の側において相當の熟練を必要とするのである。實驗といふるのは多か れ卙かれ皆このやうな性質を有するものであるが，今四の實驗においては特にこれを痛 感する。

內省記錄の中で省考となるものを記するならば，圖形を呈示した睃間よりるこれを被 覆する瞬間にハッキリ見えるといふ報告が多いことを先づ擧げなければならない。これ は知覞刺㦸の本質を深く追求せんとする者にとつては重要な意義を有するものであるが 今包は敍述を省略する。

次に影響線の長い圖形にあつては短線は線の感じを失ひ，濃い點として見えることが 雯々起る。いは山゙線が點に凝縮するのである。後に述べるやうに,この圖形にあつては 宾間距離を過小視する錯視が行はれるのであるが，これといま述べた線の凝縮とは同種 の事唡であり，同時にこれはかの同化・對比錯顓とも密接に關係するものであつて重要 な事實である。併しこれに關しては別の機會に詳論することとし娃では省く。

\section{IV，距離效果と大きさ效果}

【目的】第 II 節及び第 III 節の筫驗に使用した剌钱圖形にあつては影響線と被影響 線との距離が一定 (10 輠)であつた。そこで兩者の距離を絲へた場合に曲線に如何たる 
蘩動が起るかを見ようとするのが本節の䁈驗の目的である。

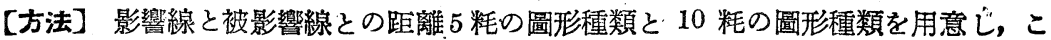
れ等を同一實驗系列中において混じて呈示した。このやうな操作を探つたのは兩種の圖 形を觀察する場合，なるべく同一の觀察態度を保たせんがためである。被驗者 4 名。他 の條件は前に準ず。

【結果】結果は表 IVに示す通りである。表において 2.5 圖形に對して疑間符のつけ られてるるのはこの圖形では長線（影響線）と短線（被影響線）とが密着して見え，短

表 IV

\begin{tabular}{|c|c|c|c|c|c|c|c|c|c|}
\hline \multirow{2}{*}{\multicolumn{2}{|c|}{ 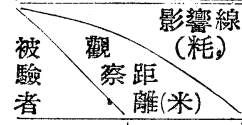 }} & \multicolumn{4}{|c|}{5 粕 距 離 } & \multicolumn{4}{|c|}{10 粍 距 雄 } \\
\hline & & 2.5 & 5.0 & 10.0 & 40.0 & 2.5 & 5.0 & 10.0 & 40.0 \\
\hline 小०O & 13.0 & $?$ & 4.0 & 6.4 & 8.7 & 25.0 & 4.3 & 3.2 & 2.6 \\
\hline 中 0 & 12.2 & $?$ & 9.5 & 8.7 & 9.1 & 59.3 & 8.3 & 4.1 & 12.5 \\
\hline 村 $a$ & 12.0 & 18.0 & 17.9 & 4.7 & 14.7 & 11.1 & 6.2 & 3.6 & 5.4 \\
\hline 妻 0 & 12.2 & 30.0 & 25.0 & 16.0 & 14.0 & 11.0 & 7.0 & 3.7 & 11.0 \\
\hline 平 均 & & $\dot{?}$ & 14.1 & 9.0 & 11.6 & 2.3 & 6.5 & 3.7 & 7.8 \\
\hline
\end{tabular}

線に對する認知時間を測定することが出來なかつたことを意味する。表に拈ける本均値 を基として 10 䊗圖形と 5 秏圖形とを比較するに，5粍圖形郎ち長線と短線との距離が 小なるものの方が認知時間が大である。換言すれば知覺過程が禁止を受けるのである。

次にこの問題を視覺刺战間の方面から考察してみる。

いま圖 6 において外側二線間の距離を絲へた場合，內部の細線を認 知する能力—一認知時間ではないー一に如何なる變化が現れるか調べ てみた。その結果によれば，外側湶が細線に接近してるるもの程刺戟 圖 6

間（視力）が惡くなる(この測定は數量的でない故，結果の報告は省 く)。たこの圖形を用ひ時間制限法によつて筫驗しても同聪な結果となる。

双て，いま述べた距離と刺战閾との關係に閵する事柄は別の方法によつても研究され 得るのである。横瀨氏は晤室に括いて白線と小光點とを呈示し, 兩者の距離が小光點の 刺価閾に及ぼす影響を調べた。その結果によれば，光點と線との距離が小である程刺戲 閾が高い。換言すれば感受性が惡い。これは上に述べた筆者の䊅果と一致してるるわけ である。民は更に角, 正方形, 圓等についても實驗してるるが,これ等の實驗結果は感 㷳效果の累積といふことによつて說明出來ると思はれる。

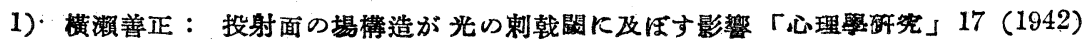
$169-188$ 


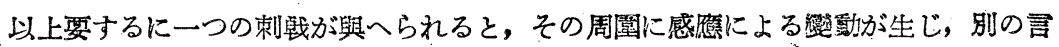
葉でいいば場が成立し，この場に括いては認知時間や剌钱闘に變化が生ずるのである。 而して感應的變動或は場の强さは剌战による興舊部位において大にして, そこから遠ざ かるにつれて小となる。このことは本節の敍速によつて明かであるが，また同化・對比 錆視の研究によつてるこのことは登明された所である。

このやうな感應的變動は影響剌㦸と被影響刺晟との距離に關係するばかりでなく，影

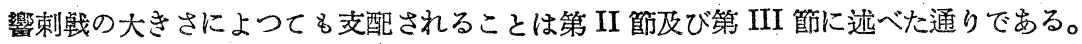
されば影響剌戱を大にするごとと影響刺餞を近づけることとは同一の效果を與へるもの であることが知られる。

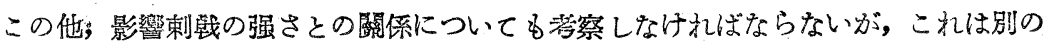
機會に讓る。

\section{$\mathrm{V}$ 認知時阔之過大視・過小視}

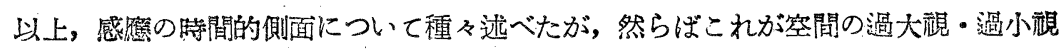
と如何なる關係を有するであらうか。以下この問题を少しく攻究してみる。

前述のや弓に，圖１（ロ）圖形の影響線が大となるにつれて初め認知時間が短くなり， その後で長くなるのであつた。然るにこの際,この圖形について室間の大きさ竞觀察す ると, 妶にも變化が起つてるることを知る。いま認知時間の實驗を行つた距離において 圖形を呈示し, 影響線と被影響線との距離の觀察を試みる。影響線と被影響線との距離 10 粍の圖形について實驗す。影響線の長さは $2,5,5,10,40,80$ 粍の 5 種でるる。圖 形る二枚宛呈示し，距離の大小を比較させる。その結果をば一對比較法の方式に從つて 處理した。4名の被驗者について調べた結果によれば，影響線が長くなるにつれてこの 距離が狹く見える。換言すれば感應の基本圖形 (圖 1 (イ)) に見られたと同じ事實が妶 にも行はれてるるのである。されば空間の過大視は認知時間の短縮に應ずるものであり， 又, 空間の過小視は認知時間の延長に應ずるるのであることが制る。或は前者は促進, 後者は禁止に應ずるといつてるよい。

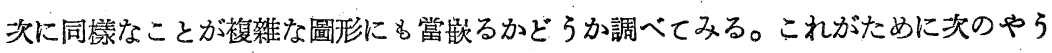
な實驗を行つた。圖 7 において ca，bd の大きさを變へる時は過大視・過小䚋の兩域が

1）小保內虎夫：感應の十般法則「心理學研究」9(1934) 53-65.

2）小保內虎夫：感應の基本法則. 前出. 
$\left.\left.\left.1\right|^{a}\right|^{2}\right|^{d}$

踏 7

1)

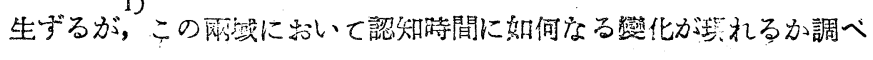
る。これがために $\mathrm{ab}$ の距離が僅かに違ふ圖形を並べて是示し，その 差異を班別させ，その辩別時閏が兩域において如何に相遠するか調べ

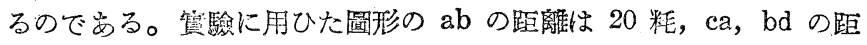

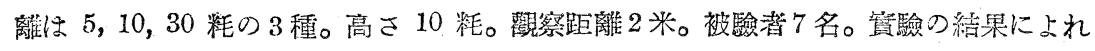

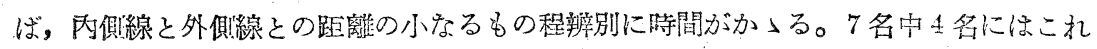

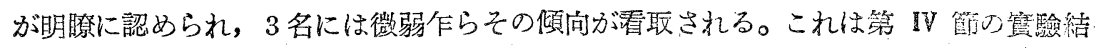

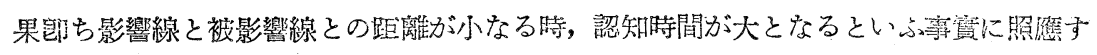
るものである。但し本節の蕒驗は方法上完全とはいひ難い點があるので继定は差空へた

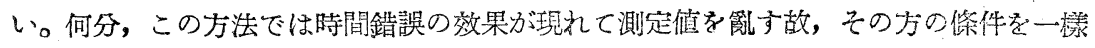

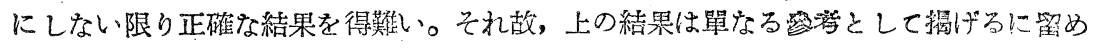
たい。

\section{VI e-t 曲線}

第 II，III 節に述べた筫驗は神經生理學における i一t 出線と類似點点有する故ここ

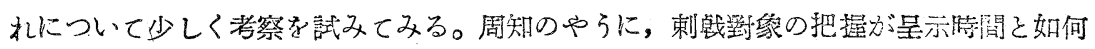

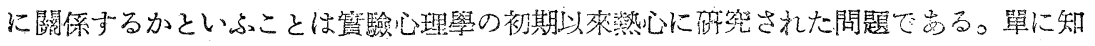
覺の場合のみならず，記譩に閣してもこれが論ぜられた。1886年カッテルは光の强さと

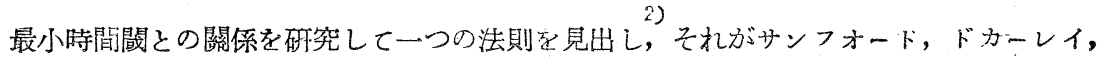
ロエスレインフフンッ等によつて引繼がれて屚究された。併しこの問题はピエロンの やろな人を除けば心理學者によつて砸究の理論的意義が十分に認められな为つた觀があ る。これに反し神經生理學に特いてはこの問題は特に重視され, 精巧, 綿密尔管驗が續 々と行はれると共に，それ等の實驗結果を土冨として刺箋理諭の建設が企てられてるる。 これにより神經生理學は追々嚴密科學の域に近づきつ〉焉る。

これを思ふ時, 實驗心理學が先驅者の苦心を無にしてこの種の䂥究を怠つたことは遗 蝛千萬と言はなければならない。さればこの種の研究がわが國心理學者によつて復興さ れることを筆者は希望してやまない。

双て，上に述べた筆者の認知時間に關する研究は生理學上の i一t (强展・時間).曲線

1) 小保內虎夫：同化・對比錯視の研究「心理學研究」8(1933) $1-20$.

2) Cattell, J. M.: Úber die Trägheit der Netzhaut und des Sehcentrums. Phil. Stud., 3 (1886) 94-127. 
と密接な閵係があることを指㸛したい。牦し兩者の比較の目的にとつては筆者の實驗よ りももつと適切なものが他にある故，紿ではそれる引用することにする。それは活字の

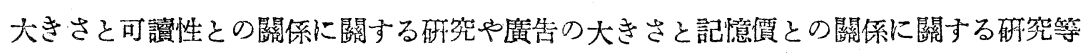
である。活字可讀性に關する研究は從來色々行はれたが, 玆では邦人の業績を引用する。 桑田博士は種々な大きさの活字多讀むに要する時間を測定し，兩者の間に存する規則性 を確めた。この磔究は一定大きさの活字を讀むには幾何の時間を必要とするかを調べた ものであるが，いま右し一定の時間內において讃文得るためには幾何の大きさの活字が

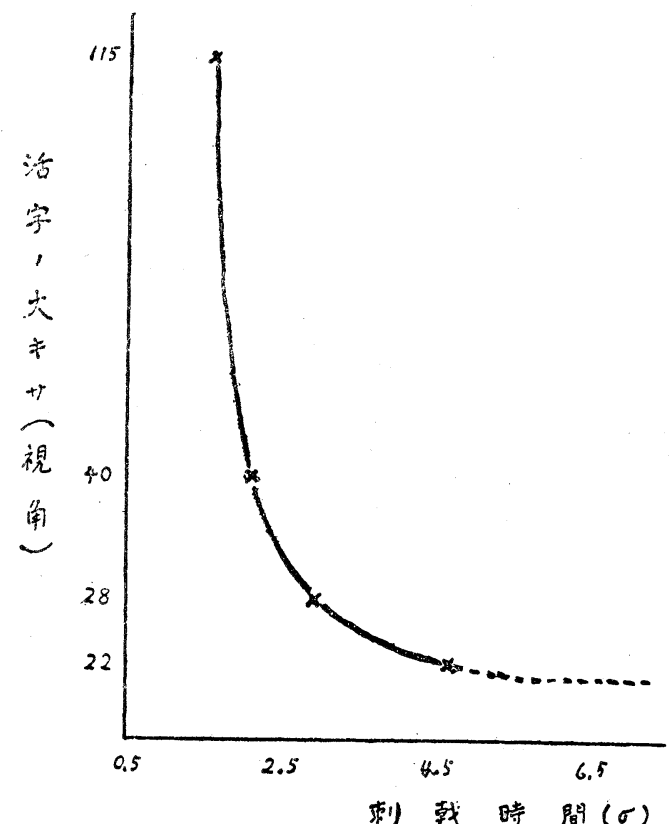

圖 8 必要かといふ問題にこれを考へ 直すならばどうなるであらうか。 圖 8 は橫軸に時間, 縱軸に活字 の大きさをとり, 桑田博士の數 值を用ひてグラフを描いたもの である。剌㦸は漢字。グラフは 3 名の被驗者對する本均であ る。グラフによつて明かでする やうに剌晟時間 (呈示時間) が 短い程剌战の面積を大にしなけ ればならない。これは $\mathrm{i}-\mathrm{t}$ 曲 線に做つて e一t (擴がり・時間) 曲線と呼心゙ことが出來る。今後， 心理學者はカッテルの $\mathrm{i}-\mathrm{t}$ 曲 線と並んでこの $\mathrm{e}-\mathrm{t}$ 曲線の意 義をよく检討することが大いに 必要と考へる。

要 約

以上述べた諸結果を簡單に要的すれば次の通りである。

1. 感應の基本圖形を少しく變形した圖形（圖 $1(ロ)$ ) を用ひて線の長さの短線認知時 間に及ぼす影響を調べることが出來る。實驗の結果によれば，影響線が大となるにつ

1）桑田芳藏：活字の可讀性に關する實驗的研究「果洋學藝雜誌」38（大正 10 年） 169-177. 
れて初めは認知時間が笠縮し，まる點を限界として延長に轉ずる。

2. 黑色矩形を影響刺賳として用ひる時は認知不良化の現象が一層著明となる。

3. 線の有する感應效果と矩形 (正方形) の有するそれとの比輘は間接的には視覺剌敦 閾を測定することによつてもなされ得る。

4. 認知時間の測定は時間制限法によつて行つても同樣の結果を與へる。

5. 影響刺䈐と被影響剌战との空間距離は認知時間を規定する一つの重要な條件である。 距離が接近すれば認知不良となり，離れつば佳良となる。このことは剌戝闘に關して も認められる。

6. 空間の過大視・過小視と認知時間との間には密接な關係がある。

7. 知覺研究のために $\mathrm{e}-\mathrm{t}$ 曲線を゙描くことが可能でありこの曲線の意義を再檢討す ることは心理學に課せられた新課題である。

附部 本報告は服部報公會の嗳助により行ひつ」ある研究の一部をなす。垃に毁して 同會の御好澺を賭らる次第である。（昭和 18 年 9 月 22 日原稿受付） 